\title{
DESIGNING ENGLISH LEARNING MATERIALS FOR INFORMATIC STUDY PROGRAM AT ENGINEERING FACULTY OF ISLAMIC UNIVERSITY OF LAMONGAN
}

\author{
Fita Faridah; Eko Sulistiono \\ pitaparidah@gmail.com ; eko.sulistiono86@gmail.com \\ Prodi Informatika, Fakultas Teknik, Universitas Islam Lamongan
}

\begin{abstract}
English learning is developing year by year through its method and every aspect in the learning process. The informatics study program has the main aim to develop the students' intelligence, knowledge, personality, and skills in a workplace for having an independent life in their future. The relevant English learning materials for particular study programs are needed to facilitate the students to achieve good English proficiency. This research is aimed at developing English learning materials for the first semester of Informatics Study Program. The researcher applied Research and Development as the research method. In the research method the researcher implemented five of Borg and Gall's Research and Development (R\&D) stages. Then, those five stages were combined with Kemp's theory of instructional model to develop and design the English materials, the steps included were: collecting the students' need, planning, developing the materials, writing the final draft, and trying out the materials. Based on the research finding, the students learn English Learning material includes seven units and in every unit cover three Basic English competence reading, speaking and writing, and also consists of several sections, namely introduction, main lesson and reinforcement.
\end{abstract}

Keywords: English Learning Material, Design, Research and Development.

\section{INTRODUCTION}

English has become an international language used by people in the world. People use this international language to share global information and to communicate in this globalization era. This situation is also caused by the fact that in the future many people need English competence, such as for working, for studying, for having business, for traveling, and other activities that use English as a tool to reach their purpose. The government has prepared people in facing the globalization by positioning English as part of education in Indonesia. As mentioned in Standards of Content (2006), the English subject is taught in junior secondary schools, senior secondary schools, even in the university.

Seeing the fact that English takes an important role in Indonesian education, English learning is developing year by year through its method and every aspect in the learning process. In addition, the development of English learning in
Indonesia is clearly seen through the change of the curriculum. For University, the informatics study program has the main aim to develop the students' intelligence, knowledge, personality, and skills in a workplace for having an independent life in their future (Standards of Content, 2006:17). In developing the students' intelligence, knowledge, personality, and skills the Faculty should facilitate them with suitable materials. The relevant English learning materials for particular study programs are needed to facilitate the students to achieve good English proficiency. Besides, it can help the students develop their abilities to communicate in English based on their work field upon graduating. According to Tomlinson (1998), materials are anything which is used by the teachers or learners to facilitate the learning of language. According to Allwright (1990) in Kitao and Kitao (1997), materials should teach students to learn, that they should be resource books for ideas and activities for 
instruction/learning, and that they should give teachers rationales for what they do. As a result, the objectives of English teaching and learning processes in Informatics study program can be reached. The specific English materials are needed to help the students to be middle-class workers after graduating from the University.

The fact using the same English materials for all study programs occurs in Engineering Faculty. Based on the observation, the English lecture used the same English learning materials for different study programs such as Civil Engineering, Electro Engineering, and Informatics. Therefore, the English learning materials do not support the students to prepare themselves for being middle-class workers. So, relevant English materials are needed for the Informatics students. This study then is designed to help English lecture of Informatics study program to conduct better English teaching learning by developing English learning process materials which can be used in the teaching of English for the first semester of Informatics Study Program at Engineering Faculty of Islamic University of Lamongan.

The nature of English Learning materials for vocational students is English for Specific Purposes which aims to meet students' needs in the target situations in which all decisions as to content and method are based on students' reasons to learn. Hutchinson and Waters (1987: 19) state that ESP is an approach to language teaching which is based on the learners' needs. It is in line with Richards (2001) that the ESP learner is usually studying English in order to carry out a particular role, such as flight attendant, mechanic, or doctor. In ESP, what is needed by the learners is not lessons in advance English, but training in the kinds of English learners would use or encounter in their specific occupations or situations.
Therefore, ESP approach suits this attempt. An ESP approach starts with an analysis of the learners' needs. Thus needs analysis will be conducted prior the development of the materials to analyze the target needs in the term of necessities, lacks, and wants as well as the learning needs (Hutchinson and Waters, 1987). The result of needs analysis can be used to determine the objective of learning, the teaching methods, kinds of activities, the language functions and language focus involved. Those would be used as the basis of developing the effective English learning materials. Materials should be developed as far as possible based on the principles of materials development proposed by Hutchinson and Waters (1987) and meet the characteristic of good materials proposed by Tomlinson (1998).

To develop the effective English learning materials, the researcher considers the principles for task-based language teaching proposed by Nunan (2004), where the materials are organized around tasks that learners will complete in the target language. Nunan also defines a pedagogical task as a piece of classroom work that involves learners in comprehending, manipulating, producing or interacting in the target language while their attention is focused on mobilizing their grammatical knowledge in order to express meaning, and in which the intention is to convey meaning rather than to manipulate form.

In developing the English learning materials, the researcher considers the tasks grading and sequencing proposed by Nunan (2004). For the process of evaluating of the developed materials, the researcher refers to the steps of evaluation of a task which is proposed by Ellis in Tomlinson (1998).

\section{METHOD}

This research is aimed at developing English learning materials for the first semester of Informatics Study Program. Therefore, it is categorize into 
Research and Development (R \& D). Borg, Borg, and Gall (2003) propose that R \& D is an industry-based development model, in which the research findings are used to design new products and procedures, which then are systematically field-tested, evaluate, and refined until they meet specified criteria of effectiveness, quality, or similar standards. The steps of doing this research followed the $\mathrm{R} \& \mathrm{D}$ stages. This research is to develop English learning materials for the first semester of Informatics Study Program at Engineering Faculty of Islamic University of Lamongan.

The instruments used to collect the data were questionnaires, interview guides and observation. This research used two approaches of collecting information: quantitative and qualitative (i.e. interview and observation). The quantitative data are obtained from questionnaires administer to the students which are given twice. The first one is for need analysis and the second one is to identify their responses toward the materials after the implementation. Meanwhile, the qualitative data is taken from the interview and class observation which also aim to support data in the questionnaire.

This research use Research and Development proposed by Borg and Gall (1983). As a basis of developing the materials, the researcher uses the System Approach Model from Dick \& Carey (in Borg, Borg, and Gall (2003) they were Research and information collecting, Planning, Develop preliminary form of product, Preliminary field testing, Main product revision- Revision of product as suggested by the preliminary field test results, Main field testing, Operational product revision, Operational field testing, Final product revision.

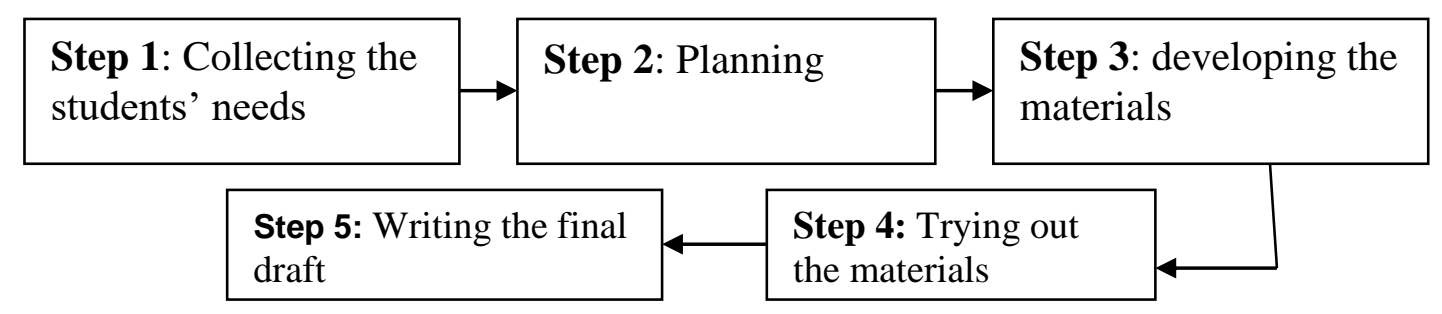

Figure 1. The illustration of Research Procedure.

\section{RESULT AND DISCUSSION}

The data were acquired by interviewing the first semester students of informatics engineering. The data include the English class, the students' needs, and the techniques of English learning. In the interview, the students explained that they learned speaking, reading, writing and grammar in the class and they stated that they easy understand English material using English specific purpose (ESP) because they feel familiar with the topic especially in reading, speaking and writing. And in the process teaching and learning the lecture using interactive teaching and learning, the students said that they like the speaking process included discussion and oral presentation. The students explained that they were active in English class. They loved to speak in a class. They were also very enthusiastic in speaking class. Therefore, speaking class was a fun class for them. The students were active to learn English through a group activity, and the lecture gave them a task to be done in group to increase their motivation.

The questionnaire distributed to 50 students in the first semester. The students were informatics class students who came to the class when the questionnaire was distributed. The results of the questionnaire indicated that students' 
motivation in learning English was high. The data showed that $80 \%$ respondents stated students like to learn English and the student's reasons are $10 \%$ the materials are easy to learn, $10 \%$ there are many new vocabularies to be learnt, $15 \%$ teacher's explanation is already clear, 20\% the activities are various, 25\% English material is fun.

And the data showed that $20 \%$ the students dislike learning English. And the reasons of students dislike English are 15\% they got bored and 5\% the materials are difficult to be understood. The questionnaire result showed that most of the students enjoy the teacher deliver the English materials with an attractive method $(85 \%)$. And the data showed $70 \%$ the questions and the tasks in English material class are fun. And sometimes the students feel difficulties in English class. Especially in the grammar $(25 \%)$, the content of the text $(16 \%)$, the explanation is too long $(8 \%)$, the topic of the material $(12 \%)$. And the activity of the process teaching learning the most favorite activity the student's like is discussion (65\%), presentation (50\%), question and answer (40\%), games (40\%), group work or group assignment (37\%), and the last is text analysis (30\%).

The data about English learning material showed that $70 \%$ the students interest with English material about the internet, $65 \%$ types of computer, $50 \%$ computer users, $45 \%$ computer system, $40 \%$ work in the IT company, $37 \%$ Ecommerce, and $30 \%$ networks. The highest result about the topic is the internet because most of students very familiar with the internet, in the daily activities most of student cannot separated from the internet. And in this unit the students felt easy to learn the task especially writing, reading and speaking.

The observation result in the first semester informatics engineering students was divided into three classes, there was only one English teacher there. The amount of students in each class is different. The class was wide and equipped with a whiteboard, board markers, eraser, LCD projector, Wi-Fi internet access and there is not computer facility in the class but every lecture brought it by her. Besides, the faculty's facilities also had a library, and free Wi-Fi internet access. The researcher concluded that the necessary support services to implement the design were available in the class even the lecture could develop the design by utilizing the support services. The complete facilities for language learning would be very helpful in finding various types of English materials.

After gathering the data needed, the researcher then developed the framework of the materials to develop materials and was designed based on the result of needs analysis. The framework includes some parts in it, they are: unit, the topic, skill focus, material, grammar focus, objective of study, and activities. The parts of the framework of the material for each of the units are described as in the figure below.

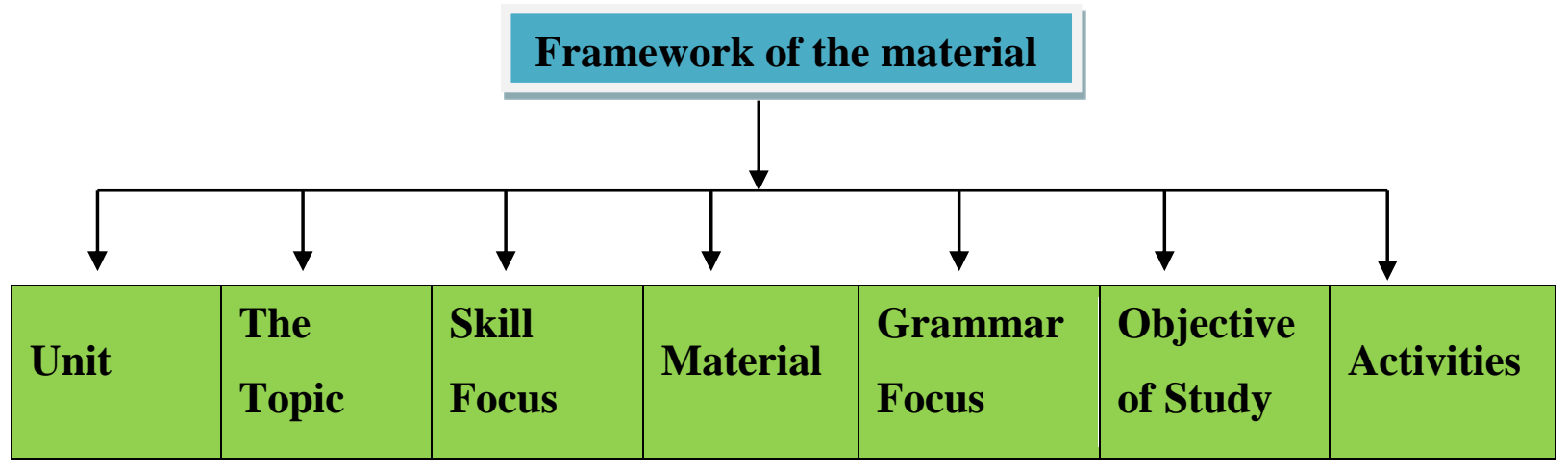

Figure 2. Framework Design

Designing English Learning Materials for Informatic Study Program at Engineering Faculty of 
The next step after finishing the framework of material was designing the unit design. The unit design of the materials consists of three parts: introduction, main lesson, and reinforcement. The design of the unit development is shown as follow:

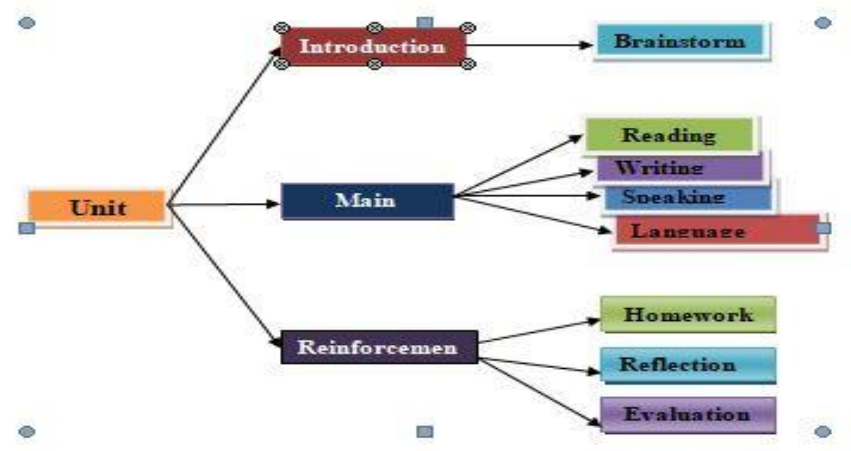

The figure shows that each of the units has three main parts. The first part is introduction activity. The second part is main activity which is considered as the main lesson of the developed materials. There are reading, writing, speaking and grammar tasks that enable students to integrate the context in the main activity to the relevant grammar. The last part is reinforcement. The last part in the reinforcement activity is reflection which gives the students an opportunity to evaluate their own understanding and lacks in relation to the unit materials. This part includes four smaller sections, they are: homework, review, and reflection. The first draft is developed by considering the result of the needs analysis, the framework of materials and the unit design. The next step after developing the materials was asking an expert to evaluate the first draft of the materials. This step was usually called as expert judgment where the expert given his evaluation and validates the materials whether they were already appropriate enough or not. Based on the revision of the expert judgment the writer change and rearrange the content of the book, And the writer provided source in every reading text that adopted from the books or internet and in the task the writer given the example in done the task. The writer also put the relevant picture in every unit in order the students more interesting in used the textbook.

\section{CONCLUSION}

The researcher applied Research and Development as the research method. In the research method the researcher implemented five of Borg and Gall's Research and Development (R\&D) stages. Then, those five stages were combined with Kemp's theory of instructional model to develop and design the English materials. This combination was also listed in the research procedure.

The first stage discuss about students need analysis, in this stage the researcher fond the information from questionnaire, observation checklist and interview the students. In this stage $75 \%$ students like English material and they need English material suitable with their major. The materials in this research are in line with the theory of English for Specific Purposes (ESP) proposed by Hutchinson \& Waters (1987). Based on the concept of ESP, the first step in developing materials is conducting needs analysis to find out students' target needs and learning needs. The next stage is construct the framework of material, the researcher then developed the framework of the materials to develop materials and was design based on 
the result of needs analysis. The framework includes some parts in it, they are: unit, the topic, skill focus, material, grammar focus, objective of study, and activities.

The next step after finishing the framework of material is designing the unit design. The unit design of the materials consists of three parts: the first is introduction, the second is main lesson including reading, speaking, writing and language work (grammar), and the last is reinforcement including homework, reflection and evaluation. And the researcher develops the final draft according to the framework of material and unit design. The next step after developing the materials was asking an expert to evaluate the first draft of the materials. This step was usually called as expert judgment where the expert given his evaluation and validates the materials whether they were already appropriate enough or not. Based on the revision of the expert judgment the writer change and rearrange the content of the book.

The researcher would like to give some suggestion to the following parties. The first is about Material developers, there are some aspects need to be considered by materials developers during the process of production and development of learning materials. Topic, input, an activities used in developing materials should be appropriate with the students' needs and the program that they take. Need analysis before developing the materials is recommended to do. The materials developers also need to reveal the knowledge and skills the students already have as well as what they still need. In short, material developers should consider the principles of language teaching to meet the needs and wants of the learners. The second is ESP Lectures, Due to the rare of ESP learning materials in public, it is suggested that teachers of ESP develop their own specific materials for their own target language learners. In developing the ESP learning materials, every English lecture can follow any approach and can develop materials by applying the principles and procedures of language teaching materials including formulating their objectives and syllabus, adapting the existing materials or creating their own materials. If a teacher has to use a textbook for some reasons, still he/she has to adjust it with the target learners. There may be some parts of the textbook which are not exactly suitable for the target learners.

\section{REFERENCES}

Brown, H. Douglas. 2001. Teaching by Principles: An Interactive Approach to

Language Pedagogy. New York: Pearson Education

2000. Principles

of Language Learning and

Teaching Fourth Edition.

New York:Longman

Ellis, Rod. 2003. Task-based Language Learning and Teaching. New York: Oxford University Press

Gall, M.D.,Gall,J.P., and Borg,W.R. 2003. Educational Research: An Introduction $7^{\text {th }}$ Edition. Boston: Pearson Education

Graves, Kathleen. 2000. Designing Language Courses: A Guide for Teachers. Boston: Heinle \& Heinle Publishers

Hutchinson, Tom and Waters, Alan. 1987. English for Specific

Purposes. Cambridge:

Cambridge University Press

Nunan, David. 2004. Task-Based Language Teaching. Camnbridge: Cambridge University Press . 1989. Designing Task for Communicative Classroom. Cambridge: Cambridge University Press

Willis, Jane. 1996. A Framework for Task-Based Learning. Singapore: Longman Singapore Publisher. 